\title{
Efforts to Increase Marketing Performance of Small and Medium Enterprises in Central Java, Indonesia
}

\author{
Mudiantono Soekirman \\ Universitas Diponegoro \\ Fajar Ayu Suryani \\ Universitas Diponegoro \\ mumuk_undip@yahoo.co.id
}

\begin{abstract}
Business competition in the current era of globalization requires companies to have a strategy to win the market. Strategic management has an important role for the survival of the company. The existence of such competition is also felt by small businesses such as Small and Medium Enterprises (SMEs). The increase in the number of SME units in Central Java was not followed by an increase in average sales of SMEs. This study aims to analyze the effect of distribution channel, ERP implementation and entrepreneurial orientation on marketing performance with competitive advantage as an intervening variable. The population in this study were small and medium enterprises owners in Central Java. Six hypothesis were formulated for this study. To test those hypothesis, this study used 104 respondent. Structural Equation Model (SEM) was applied to this study using AMOS 24 as a tool. The results of this study shows that competitive advantage is the most variable in influencing the marketing performance, while this competititve advantage has entrepreneurial orientation as highest variable in influencing it. This study suggests that if SMEs want to increase their marketing performance, they must increase their competitive advantage. This competitive advantage can be increase by increasing the entrepreneurial orientation.
\end{abstract}

Keywords : distribution channels, ERP implementation, entrepreneurial orientation, competitive advantage, marketing performance

\section{Introduction}

Small and Medium Enterprises (SMEs) have important roles for the national economy. According to Ministry of Cooperation and SMEs (2014), there are at least five roles of SMEs in Indonesian economy, namely: SMEs are main actors in Indonesia economic activities in various sectors, provides largest employment, are important in developing local economic activities and community empowerment., are creators of new market and sources of innovation, and are able to maintain the balance of payments through export activities The growth of Small and Medium Enterprises is always positive. In Central Java. The number of Small and Medium Enterprises is always growing every year. However, the growth of the SMEs units was not followed by the growth of average turnover per SMEs. Table 1 shows the development of each SMEs sector whereas in 2016 until 2017 the average number of SMEs expanded by $15.5 \%$. Labor absorption increased by $16 \%$ whereas in 2016 SMEs could absorb 791,767 workers, and increased by 126,688 workers so that there were 918,455 people absorbed into SMEs workforce. The number of assets in 2017 increased by 
$14.6 \%$ from the previous year. Meanwhile, the turnover increased by $13 \%$ from 2016. In table 1.3 it can be seen the decline in the average per SMEs whereas in 2016 the average turnover per SMEs is 0.376 billion per year, decreased to 0.368 billion per year.

Annual increasing number of SMEs causes higher competition and tighter market. The essence of success is competition, thus, enterprises must have a competitive strategy to win market competition. SMEs have to set strategies on improving competitive advantage and maintaining the market. So that, product sales from SMEs could be increased.

The level of competition from an enterprise could be observed through a enterprise development and the number of similar enterprises engaged in the same field, as well as offering similar products and services. These conditions push the company management to continue making efforts on improvements, maintain and advance the business among competitors. Competitive advantage is obtained when an organization develops or acquires a set of attributes (or executes actions) that enable it to out perform its competitors (Wang, Lin and $\mathrm{Chu}, 2011)$.

Competitive advantage thus refers to conditions in which products of enterprises or service is considered better than its competitors' products. The most common type of competitive advantage is because the product or service has a low price or is different from competitors (Dash, 2013).

\section{Literature Review and Hypotesis}

\section{Critical Success Factors}

Lečić and Kupusinac (2013). stated that marketing performance could be obtained from the application of ERP (Enterprise Resource Planning) through competitive advantage. Apart from implementing ERP in the enterprise, marketing performance and competitive advantage could also be obtained from the existence of an entrepreneurial orientation (Rezaei and Ortt, 2018). Another variable that can affect marketing performance and competitive advantage is the presence of effective distribution channel (Kuswantoro, et al 2012).

\section{Effect of Distribution Channel on Competitive Advantage}

According to Saremi, Masomeh and Zadeh (2014) distribution channels are a group of affiliated organizations and individuals who place products or services from producers to end consumers, while the distribution channel is a link between producers and consumers to be able to connect each other. A successful enterprise must have maintained a strong distribution channel system, because a strong distribution system could expand the market share of the enterprise. Distribution channel is an individual or group of companies that aims to assist and take over rights in the process of transferring products from producers to consumers. The presence of distribution channel make the process of distributing products to consumers is more optimal. Distribution channels are one of the sources of the enterprise competitive advantage in the field of marketing (Mwanza and Ingari, 2015).

Szopa and Pękała (2012) in their study explained that distribution channels are groups that depend on each other organizational unit, which takes part in the process of flowing products or services from producers to buyers. Distribution channels must be carried out effectively by the enterprise in order to get the results expected by the enterprise. If the distribution channel is used optimally, the enterprise should have the ability to seize the 
INOBIS: Jurnal Inovasi Bisnis dan Manajemen Indonesia Volume 04, Nomor 01, Desember 2020

Mudiantono Sokirman, Fajar Ayu Suryani

market, have a wider market coverage and increase the number of potential customers. Enterprises that able to effectively implement distribution channels would likely be able to achieve competitive advantage.

\section{H1: Distribution channels have a positive effect on competitive advantage.}

\section{Effect of Distribution Channel on Marketing Performance}

The presence of distribution channell in marketing resulted in increasing sales, market range and prodit. The enterprise should be able to market the product more effectively and increase the ability of enterprise to provide, expand dan respond market changes faster (Amara, 2012).

Kuswantoro, et al (2012) in his study explained that a good distribution channel could improve market range of products, so that there would increasing number of costumers. The existence of a good distribution channel could also provide effectiveness and efficiency in the process of product distribution. These points resulted in better increased marketing.

The accuracy of the distribution channel selection process to integrate the interests of distributors and outlets in the distribution channel and maintain a form of cooperation can increase market share, which is one of the marketing performance indicators. Therefore one of the determinants of success from marketing performance is the effectiveness of distribution channels (Nasution, 2014).

\section{H2: Distribution channels have a positive effect on marketing performance.}

\section{Effect of ERP Implementation on Competitive Advantages}

An ERP system is integrated software that covers all aspects of the company such as aspects of production, sales, finance, accounting, human resources and includes managing all relevant business resources (Lečić and Kupusinac, 2013). Mudiantono, et al (2018) in his study explained that thr competitive advantage variable could be increased if the successful implementation of ERP was increased. Research conducted by Contador and Ferreira (2012) stated that the use of information systems has an important role in achieving competitive advantage of the company.

The implementation of ERP in the company reflects the competitive advantage strategy of manufacturing companies in Indonesia Dantes and Hasibuan (2011). The competitive advantage strategy itself is the main factor to improve the performance of the company (Hidayat and Akhmad, 2016).

\section{H3: ERP Implementation has a positive effect on Competitive Advantage}

\section{Effects of Entrepreneurial Orientation on Competitive Advantage}

Competitive advantage is one essential point for an enterprise. To increase the competitive advantage, entrepreneurial orientation could be impleme. Enterpreneurial orientation, based ln Zeebare and Siron (2017) have positive and significant impact on competitive advantage.

The internal environment factors include entrepreneurial management which consists of a level of emphasis placed on strategic orientation, resources orientation, management 
structure entrepreneurial culture development, reward philosophy, and the entrepreneurial orientation is related with personal characteristics of the entrepreneurs (Islam, Khan and Obaidullah, 2011). A study by Sirivanh, Sukkabot and Sateeraroj (2014) also explained that Enterpreneurial orientation have positive and significant impact on competitive advantage.

\section{H4: Entrepreneurial orientation has a positive effect on competitive advantage.}

\section{Effect of Entrepreneurship Orientation on Marketing Performance}

The research conducted by Santra (2018) revealed that the entrepreneurial orientation hypothesis has a positive effect on rejected marketing performance. That way entrepreneurial orientation does not have a positive effect on marketing performance. But this is inversely proportional to the research conducted by Rezaei and Ortt (2018). The study revealed that entrepreneurial orientation had a positive and significant effect on marketing performance.

These results are also supported by research conducted by Bucktowar, Kocak and Padachi (2015) which revealed that entrepreneurial orientation has a positive and significant effect on marketing performance.

\section{H5: Entrepreneurial orientation has a positive effect on Marketing Performance.}

\section{Effect of Competitive Advantages on Marketing Performance}

The positive influence of competitive advantage on performance has been proven by various studies. The enterprise competitive advantage could be created by providing a means to outperform its competitors and also by paying attention to external factors (Pardi et al., 2014). Research conducted by Pardi et al. (2014) and Zaini, et al (2014) revealed that competitive advantage has a positive and significant effect on marketing performance.

This statement is supported by research conducted by Raharjo, et al (2015) and May, et al (2013) which revealed that competitive advantage has a positive and significant effect on marketing performance. The concept of competing strategies is always directed at improving marketing performance such as increasing sales, profits of customers and companies in the future (Mudiantono et al., 2018).

H6: Competitive advantage has a positive effect on Marketing Performance.

\section{Theoritical Framework}

Based on the hipothesis formulation above, the model can be constructed.

\section{Figure 1}

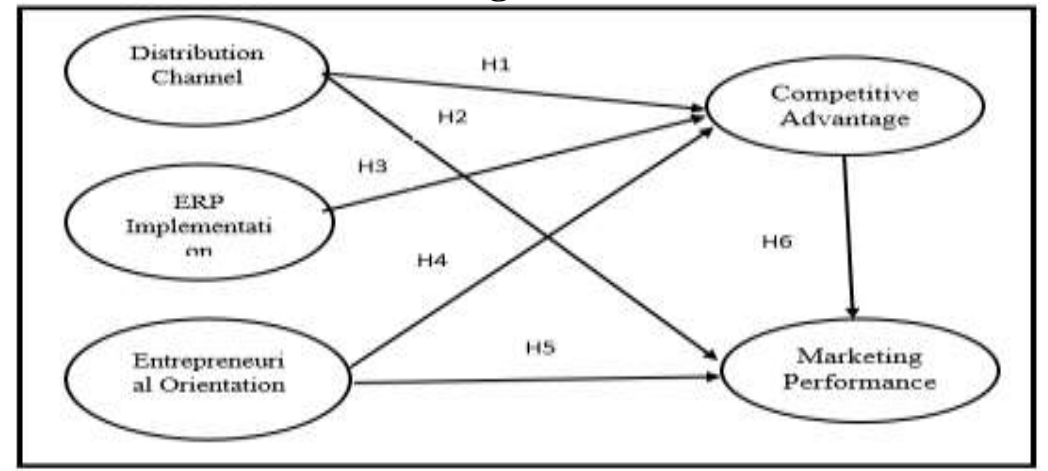

Source : Santra (2018), Dantes dan Hasibuan (2011), Mudiantono et al (2018),Zeebaree and Siron (2017), Zaini et al.(2014), Nurseto (2016), Hazizah (2013). 


\section{Research Method}

The type of data used in this study were primary and secondary datas. Primary data were obtained from respondents, namely the owners of SMEs in Central Java, while secondary data were obtained from journals, the internet and the Cooperative and SMEs Department in Central Java.

This study was focused on SMEs in Central Java with a total sample of 104 SMEs in Central Java that had implemented ERP with non-probability sampling and purposive sampling methods.

Data collection methods used in this study were interview and questionnaire methods. The analysis technique in this study used the Structural Equation Model (SEM) with AMOS software which was used in testing H1 to H6.

\section{Result and Discussion}

\section{Data Analysis}

Based on Table 2, the largest number of respondents are those engaged in food and beverages (culinary), as much as $50 \%$ of the total respondents, then convection $15 \%$, and the least is in the field of batik which is only $2 \%$ of the total respondents.

Table 2

Respondents' Type of Enterprises

\begin{tabular}{|c|c|c|c|}
\hline No & Enterprise Type & Amount & Percentage \\
\hline 1. & Culinary (foodsand beverages) & 50 & $50 \%$ \\
\hline 2. & Furniture & 10 & $10 \%$ \\
\hline 3. & Convection & 15 & $15 \%$ \\
\hline 4. & Weaving & 10 & $10 \%$ \\
\hline 5. & Retail & 5 & $5 \%$ \\
\hline 6. & Ceramics & 7 & $8 \%$ \\
\hline 7. & Services & 5 & $5 \%$ \\
\hline 8. & Batik & 104 & $2 \%$ \\
\hline & Total & & $100 \%$ \\
\hline
\end{tabular}

Source: Processed primary data 2018

Based on Table 3, the Enterprise Resource Planning (ERP) module that is widely used by enterprises is a sales module that reaches $32 \%$ of the total modules used by respondents. Next is a purchase module of $22 \%$, an accounting module of $16 \%$, a warehouse module of $13 \%$, an administrative module of $10 \%$, an HR module of $7.5 \%$ and no one uses a cooperative and savings and loan management module. 
Table 3

ERP Table Type Used by Respondents

\begin{tabular}{|c|c|c|c|}
\hline No & Module & Amount & Percentage \\
\hline 1. & $\begin{array}{c}\text { Management of Loan-Saving } \\
\text { and Cooperation }\end{array}$ & 0 & - \\
\hline 2. & Selling Module & 87 & $32 \%$ \\
\hline 3. & Purchasing Module & 58 & $22 \%$ \\
\hline 4. & Warehouse Module & 35 & $13 \%$ \\
\hline 5. & Account Module & 43 & $16 \%$ \\
\hline 6. & Human Resources Module & 20 & $7,5 \%$ \\
\hline 7. & Administration Module & 26 & $10 \%$ \\
\hline & Total & $\mathbf{2 6 9}$ & $\mathbf{1 0 0 \%}$ \\
\hline
\end{tabular}

Source: Processed primary data 2018

The result of data analysis can be seen in Fugure 2.

\section{Figure 2}

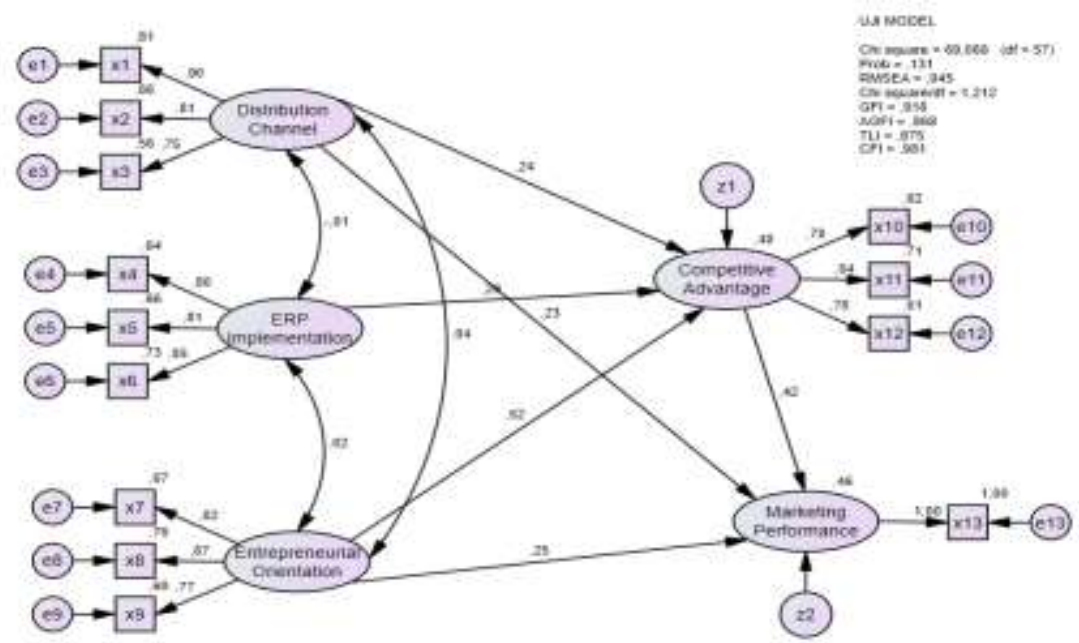

The results of the full SEM model analysis meet all the criteria of the model fit according to the standards used. These results can be seen in Table 4 below:

Table 4

\begin{tabular}{|c|c|c|c|}
\hline $\begin{array}{c}\text { Goodness of Fit } \\
\text { Indeks }\end{array}$ & Cut-off Value & Result & $\begin{array}{c}\text { Model } \\
\text { Evaluation }\end{array}$ \\
\hline Chi - Square & Kecil $(<\mathbf{7 5 , 6 2 4 )}$ & $\mathbf{6 9 . 0 8 8}$ & Fit \\
Probability & $\geq 0.05$ & 0.131 & Fit \\
RMSEA & $\leq 0.08$ & 0.045 & Fit \\
Chi square / df & $\leq 2.00$ & 1.212 & Fit \\
GFI & $\geq 0.90$ & 0.918 & Fit \\
AGFI & $\geq 0.90$ & 0.868 & Marginal \\
TLI & $\geq 0.90$ & 0.975 & Fit \\
CFI & $\geq 0.90$ & 0.981 & Fit \\
\hline
\end{tabular}

Source : Processed Primary Data 2018 
Table 5 shows that the model meets the value of the cut-of-value so that it can be concluded that the model used is fit. Based on Figure 2, the Regresion weight structural equational value is as follows:

Table 5

\begin{tabular}{|c|c|c|c|c|c|c|}
\hline & & & Estimate & S.E. & C.R. & $\mathrm{P}$ \\
\hline $\begin{array}{l}\text { Competitive } \\
\text { Advantage } \\
\text { Competitive }\end{array}$ & $<---$ & Distribution Channel & 0.291 & 0.122 & 2.387 & 0.017 \\
\hline $\begin{array}{l}\text { Advantage } \\
\text { Competitive }\end{array}$ & $<---$ & $\begin{array}{l}\text { ERPImplementation } \\
\text { Entrepreneurial }\end{array}$ & 0.295 & 0.114 & 2.603 & 0.009 \\
\hline $\begin{array}{l}\text { Advantage } \\
\text { Marketing }\end{array}$ & $<---$ & Orientation & 0.597 & 0.130 & 4.611 & $* * *$ \\
\hline $\begin{array}{l}\text { Performance } \\
\text { Marketing }\end{array}$ & $<--$ & Competitive Advantage & 0.508 & 0.136 & 3.736 & $* * *$ \\
\hline $\begin{array}{l}\text { Performance } \\
\text { Marketing }\end{array}$ & $<---$ & $\begin{array}{l}\text { Distribution Channel } \\
\text { Entrepreneurial }\end{array}$ & 0.338 & 0.130 & 2.607 & 0.009 \\
\hline Performance & $<---$ & Orientation & 0.352 & 0.145 & 2.422 & 0.015 \\
\hline
\end{tabular}

\section{Hypothesis Testing}

The proposed hypothesis can be tested by observing the value of the critical ratio and the level of significance contained in regression weight, where the value of C.R $\geq 1.96$ and $P$ $\leq 0.05$ is required as a condition for receiving the hypothesis. Based on Table 5 , the results of hypothesis testing using AMOS analysis all hypothesis are accepted.

\section{Conclusion and Management Implication Conclusion}

The purpose of this study was to analyze the influence of distribution channels, ERP implementation and entrepreneurial orientation on marketing performance with competitive advantage as an intervening variable in the study of SMEs in Central Java. Based on respondents 'answers in this study, the most widely used ERP module is the sales module, and the respondents' business fields in this study are mostly in the culinary field. All hypotheses in this study show a positive and significant influence, and the variable that most influences marketing performance is the variable of competitive advantage.

\section{Management Implication}

The results of the study show that the variables that greatly influence marketing performance are the competitive advantages with the most influential indicators are the ability to capture the market. The results also show that the variables that greatly influence marketing performance are the competitive advantages with the most influential indicators are the ability to capture the market. Therefore, SMEs must increase competitive advantage. The most important indicator in influencing the high competitive advantage possessed by SMEs is the ability to capture the market, SMEs are expected to have the ability to seize the market by offering products at competitive prices from competitors and able to create 
INOBIS: Jurnal Inovasi Bisnis dan Manajemen Indonesia

Volume 04, Nomor 01, Desember 2020

Mudiantono Sokirman, Fajar Ayu Suryani

products that are not easily copied by competitors and provide more value to customers on the products or services offered.

With the existence of competitive advantages possessed by SMEs, it is expected that SMEs have a broad market share and increased sales and products that are widely known to consumers

\section{References}

Amara, S. (2012) "The Effect of Marketing Distribution Channel Strategies on A Firms Performance Among Commercial Banks in Kenya" hal.9-35.

Buctowar, R., Kocak, A. and Padachi, K. (2015) "Entrepreneurial Orientation, Market Orientation and Networking : Impact on Innovation and Firm Performance" Journal of Development Entrepreneurship, 20(04).

Contador, J.C dan Ferreira, A.A. 2012. It Outsourcing: Methodology For Selecting Suppliers Criterion For Competitive Advantage. Journal of Information Systems and Technology Management. Vol.9, no.1, pp. 123-146

Dantes, G. R. dan Hasibuan, Z. A. (2011) "Enterprise Resource Planning ( Erp ) Implementation: Any Competitive Advantage for the Company? ( Case Study: Erp Implementation in Indonesia )," Information Systems, (September), hal. 79-86.

Dash, A. K. (2013) "Competitive Advantage," International Journal of Application or Innovation in Engineering Management IJAIEM, 2(12), hal. 7-10.

Hidayat, R. dan Akhmad, S. (2016) "Effect of the Enterprise Resource Planning (ERP) on Competitive Advantage and Performance of Manufacturing Firms in Indonesia," Journal of Engineering, 11(10), hal. 2298-2303.

Islam, Md. A., Khan, M.A., Obaidullah,.A. Z. M., \&Alam, M. S. (2011). "Effect of Entrepreneur and Firm, Characteristics on the Business Success of Small and Medium Enterprises (SMEs) in Bangladesh", International Journal of Business and Management. 6(3), 289-299.

Kuswantoro Ferry, M. Mohd Rosli, Radiah Abdul and Hamidreza Ghorbani (2012) "Impact of Dsitribution Channel Inovation on the Performance of Small and Medium Enterprises" International Business and Management, Vol 5, No 1, pp 52-61

Lečić, D. dan Kupusinac, A. (2013) “The Impact of ERP Systems on Business,"TEM journal, 2(6), hal. 323-326.

May, J., Dhillon, G. And Caldeira, M. 2013. Defining Value-Based Objectives for ERP Systems Planning. Decision Support Systems, Vol. 55 No. 1, pp 98-109

Mudiantono, Prasetiono, Dul Mu'id, Herry Laksito and Rini Nugraheni (2018) "The Role of ERP in Increasing Marketing Performance of SMEs in Central Java, Indonesia," Advanced Science Letters, 24(12), pp. 9706-9709. Doi: 10.1166/asl.2018.13119.

Mwanza., P and Ingari., B. (2015). Strategic Role of Distribution as a Source of Competitive Advantage in Fast-Moving Consumer Goods in Kenya. International Journal of Scientific and Research Publications, 5(10), page. 1-14.

Nasution, A. A. (2014) “Analisis Kinerja Pemasaran PT. Alfa Scorpii Medan," Riset Akutansi dan Bisnis, 14(2002), hal. 52-65.

Pardi et al. (2014) "The Effect of Market Orientation and Entrepreneurial Orientation toward Learning Orientation, Innovation, Competitive Advantages and Marketing Performance," European Journal of Business and Management, 6(21), hal. 22222839. 
Ministry of Cooperative and Micro, Small and Medium Enterprise of Indonesia. The Role of Nicro, Small and Medium Enterpises on National Economy (2014).

Raharjo, S.T., Mudiantono, Perdhana, M.S. 2015 SME's Enterprise Resource Planning Implementation, Competitive Advantage, and Marketing Performance: Finding from Central Java, Indonesia. Journal of Entrepreneurship, Business and Economics, Vol.4, No. 1, pp 22-44

Rezaei, J. dan Ortt, R. (2018) "Entrepreneurial orientation and firm performance: the mediating role of functional performances," Management Research Review, 41(7), hal. 878-900. Doi: 10.1108/MRR-03-2017-0092.

Santra, I. K. (2018) "Entrepreneurial Orientation and Marketing Performance of Budget Hotel SMEs in Bali Island." International Journal of Entrepreneurship, 22(4), hal. 111.

Saremi, H., Masomeh, S. dan Zadeh, M. (2014) "Management of Distribution Channels." Indian J.Sci.Res, 5(3), hal. 452-456.

Sirivanh, T., Sukkabot, S. dan Sateeraroj, M. (2014) "The Effect of Entrepreneurial Orientation and Competitive Advantage on SMEs' Growth: A Structural Equation Modeling Study," International Journal of Business and Social Science, 5(6), hal. 189-195. Doi: 10.1007/BF01976328.

Szopa, P. dan Pękała, W. (2012) "Distribution Channels and Their Roles," PolishJournal of Management Studies, 6, hal. 143-150.

Wang, Wen-Cheng, Chien-Hung, L. dan Ying-Chien, C. (2011) "Types ofCompetitiveAdvantage and Analysis," International Journal of Businessand Management, 6(5), hal. 100-104. Doi: 10.1007/s004360050358.

Zeebaree, Y. M. R. dan Siron, R. B. (2017) "International Review of Management and Marketing The Impact of Entrepreneurial Orientation on Competitive Advantage Moderated by Financing Support in SMEs," International Review of Management and Marketing, 7(1), hal. 43-52.

Zaini, A., Hadiwidjojo, D., Rohman, F and Maskie, G. (2014) "Effect Of Competitive Advantage As A Mediator Variable Of Entrepreneurship Orientation To Marketing Performance," IOSR Journal of Business and Management, 16(5), page. 05-10. Doi: 10.9790/487x-16510510. 